\title{
Various types of dialogues and features of a corrective dialogue in the Qur'an
}

\begin{tabular}{|c|c|}
\hline $\begin{array}{l}\text { Author: } \\
\text { Majid Maaref }\end{array}$ & \\
\hline $\begin{array}{l}\text { Affiliations: } \\
{ }^{1} \text { Department } \\
\text { Quranic Scien } \\
\text { of Theology ar } \\
\text { Sciences, Univ } \\
\text { Tehran, Iran }\end{array}$ & $\begin{array}{l}\text { f Hadith and } \\
\text { ces, Faculty } \\
\text { d Islamic } \\
\text { ersity of }\end{array}$ \\
\hline $\begin{array}{l}{ }^{2} \text { Department } \\
\text { Religion and } \\
\text { Faculty of The } \\
\text { Religion, Univ } \\
\text { Pretoria, Sout }\end{array}$ & $\begin{array}{l}\text { f Science of } \\
\text { lissiology, } \\
\text { ology and } \\
\text { rsity of } \\
\text { Africa }\end{array}$ \\
\hline $\begin{array}{l}\text { Research Proj } \\
\text { Project Leader } \\
\text { Project Numb }\end{array}$ & $\begin{array}{l}\text { ect Details: } \\
\text { : M. Sukdaven® } \\
\text { er: } 04616546\end{array}$ \\
\hline $\begin{array}{l}\text { Description: } \\
\text { Prof. Maaref is } \\
\text { in the research } \\
\text { 'Religion in Dia } \\
\text { directed by Dr } \\
\text { Sukdaven, Dep } \\
\text { Science of Reli } \\
\text { Missiology, Fa } \\
\text { Theology and } \\
\text { University of P }\end{array}$ & $\begin{array}{l}\text { participating } \\
\text { project, } \\
\text { logue', } \\
\text { Maniraj } \\
\text { artment of } \\
\text { gion and } \\
\text { culty of } \\
\text { Religion, } \\
\text { retoria. }\end{array}$ \\
\hline $\begin{array}{l}\text { Correspondin } \\
\text { Majid Maaref, } \\
\text { maaref@ut.ac }\end{array}$ & $\begin{array}{l}\text { g author: } \\
\text {.ir }\end{array}$ \\
\hline $\begin{array}{l}\text { Dates: } \\
\text { Received: } 07 \mathrm{~J} \\
\text { Accepted: } 07 \\
\text { Published: } 26\end{array}$ & $\begin{array}{l}\text { une } 2018 \\
\text { Aug. } 2018 \\
\text { Nov. } 2018\end{array}$ \\
\hline $\begin{array}{l}\text { How to cite th } \\
\text { Maaref, M., } 20 \\
\text { types of dialog } \\
\text { features of a c } \\
\text { dialogue in the } \\
\text { HTS Teologiese } \\
\text { Theological St } \\
\text { a5140. https:// } \\
10.4102 / \text { hts.v7 }\end{array}$ & $\begin{array}{l}\text { is article: } \\
18, \text { 'Various } \\
\text { zues and } \\
\text { orrective } \\
\text { Qur'an', } \\
\text { Studies/ } \\
\text { udies 74(3), } \\
\text { /doi.org/ } \\
74 i 3.5140\end{array}$ \\
\hline $\begin{array}{l}\text { Copyright: } \\
\text { @ 2018. The A } \\
\text { Licensee: AOSI } \\
\text { is licensed und } \\
\text { Creative Comn } \\
\text { Attribution Lic }\end{array}$ & $\begin{array}{l}\text { uthors. } \\
\text { S. This work } \\
\text { ler the } \\
\text { nons } \\
\text { ense. }\end{array}$ \\
\hline Read online: & \\
\hline 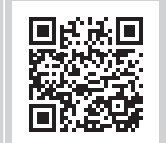 & $\begin{array}{l}\text { Scan this QR } \\
\text { code with your } \\
\text { smart phone or } \\
\text { mobile device } \\
\text { to read online. }\end{array}$ \\
\hline
\end{tabular}

The Qur'an is the book of Allah's dialogue with humans. At the same time, this book itself contains a diverse number of dialogues including the prophets' dialogues with people, the wise peoples' dialogues, the divine selected figures' dialogue with people, the angels' dialogue with humans, various classes of humans' dialogue with each other, human's dialogue with his or her own organs and such likes. The dialogues in the Qur'an have various types of attitudes ranging from criticism, alteration, trials and reforms whose latter samples are manifested in the prophets' dialogue with their people. To be in agreement with the truth, to be authentic and to be proportional with the society, customs, profitability, clearness, purity, acceptability and bearing, beauty and goodness are all the features of ideal dialogues and speeches in the Qur'an. Features such as rationalism, religious tolerance, endurance and self-constraint, humbleness in words, sympathy with the opponents with an emphasis on commonalities and avoiding any kind of polemic debates and violence in the process of dialogue, and observing politeness and dignity of the addresses are among the most important features of corrective dialogue in the Qur'an.

\section{Introduction: The Qur'an, the book of dialogue}

The Qur'an as the Muslims' religious book is basically Allah's dialogue with humans. The first addressee of this dialogue was the Messenger of Allah (peace be upon him [p.b.u.h.]), and not only the Muslims but also the whole human race are the addressees of the messages of this book as it has been mentioned in the following verses in Qur'an Surahs:

شهر رمضان الذى انزل فيه القرآن هدى للناس ( البقره 185).

The month of Ramadan in which was revealed the Qur'an, a guidance for mankind¹. (Qur'an 2012; Surah 3:18)

ان هذا القر آن يهدى للتى هى اقوم ( الاسر اء ، 9)

Indeed, this Qur'an guides to that which is most suitable. (Surah 17:9)

At the same time, the Qur'an itself narrates many dialogues, a list of which is presented as follows:

- Allah's dialogue with the angles

- angels' dialogue with humans

- prophets' dialogue with people

- Satan's dialogue with humans

- the dialogue between the people of the paradise and the people of the hell

- the dialogue of the people of the hell with each other

- the prophets' dialogue with animals

- the human's dialogue with himself or herself and his or her body organs

- the humans' dialogue with each other

- the wise people's dialogue and the selected figures' dialogue with people

- Allah's dialogue with elements of the entity.

Therefore, it will not be an exaggeration to conclude that the Qur'an as a religious book, which undertakes to guide humans, apart from reporting the issues, has frequently utilised the framework of the dialogue as an expressive model and has been able to establish an effective relationship with its readers. It is worth noting that the term 'dialogue' is considered as a conversation between two or more ones to exchange ideas or opinions on a particular issue. The monologues of the Qur'an do not count as part of a broader dialogue in this article.

The contribution of this article is to organise the categories and specifications of the dialogue from the Qur'an's viewpoint. As the scope of this article is to provide the Qur'an's opinion about the

1.All translations are developed by open-source Muslim community, Noble Quran, available online at www.quran.com. 
dialogue, only references from the Qur'an have been cited in this article.

\section{The logic model of types of dialogue in the Qur'an}

Based on Nahl (Surah 16:125), it is possible to identify a logical model for types of dialogue which states:

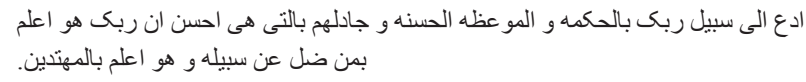

Invite to the way of your Lord with wisdom and good instruction, and argue with them in a way that is best.

Indeed, your Lord is most knowing of who has strayed from His way, and He is most knowing of who is [rightly] guided.

According to Allameh Tabatabaei (1990:Vol. 12, 372), the three ways that have been stated by the Almighty Allah are in agreement with the three logic methods including 'reasoning', 'oration' and 'polemic argument'.

In this verse, the wisdom that has been considered an equivalent to reasoning is, in principle, a favourable style in the process of dialogue, so that there has been no need to restrict it with an attribution.

However, the Almighty Allah has limited the oration with the adverb of good and also the argument with 'التى هى احسن [And tell my servants to say that which is best. Indeed]. This signifies that some of the orations are not good. Also, some of the arguments are good and some are better and some others might have no goodness; otherwise, Allah would not have restricted the oration with the attribute of goodness and argument with the attribute of 'better' (Tabatabaei 1990:Vol. 12, 372).

The other important point in this verse is that the diversity in the threefold method in the process of dialogue is because of diversity of addressees and their spirit and talent. That is to say, some people accept the facts by presenting wisdom and reasoning and some others will only submit to the ideas of others by listening to the good orations.

Some others should be treated through polemic arguments but, of course, in the best way through dialogue and by presenting the facts. Thus, it is necessary for the utterer to have knowledge about the addressee's spirit and then select one of the three mentioned methods.

However, concerning the difference of the threefold style, the logic scholars believe that the wisdom that has been adapted with reasoning is an analogy whose preliminaries are exclusively composed of certain propositions, and consequently, its result will be fully certain and there is no room left for doubt or questions in it (Khansari 1980:119).

An oration or sermon is a speech whose preliminaries are well-known premises, presumed premises and accepted premises and the listener, in light of trust in the utterer's personality, accepts it and receives the highest effect. One of the factors that cause perfection of influence of the oration is the use of allegory, stories and tales (Khansari 1980:233-234).

However, a polemic argument includes a reason that is put forth to make the opponent give up on what he or she is disputing, without having an enlightening feature of truth. In other words, in a polemic argument, what is accepted by the opponent or accepted by all people is employed against the opponent to reject his or her claim, and the result is his or her silence (Tabatabaei 1990:Vol. 12, 371; Khansari 1980:224, 323).

An example of polemic treatment in the Qur'an (21:62-66) is Abraham's ${ }^{2}$ dialogue with his people after breaking the idols and attributing this action to the big idol which made the people of that Hazarat to regain their awareness and admit that the idols are not able to make any profit or damage:

He said, Then do you worship instead of Allah that which does not benefit you at all or harm you? (Qur'an 21:62)

\section{Other types of discourse or dialogue frameworks in the Qur'an}

After expressing three types of main dialogues (wisdom or reasoning, oration or sermon and the best polemic argument), which had been employed by the holy prophet of Islam (p.b.u.h.) and consequently his followers, the holy Qur'an has spoken about another type of dialogue. Some of these types of dialogues have been employed by the believers and some others are in connection with the non-believers, especially those who stand against the truth-seeking peoples. A number of these dialogues include the following.

\section{A peaceful discourse (talk)}

If the three methods- that is, wisdom, oration and the best argument- are not effective, a fourth method is recommended, which is to leave alone the addressees and have a peaceful and generous engagement with him or her. In verse 63 of Forqan (Surah 25:63), 'A peaceful discourse' has been mentioned as one of the features of believers of Allah, where it states:

و عبادالرحمن الذين يمشون على الارض هوناو اذا خاطبهم الجاهلون قالو ا سلاما

And the servants of Allah, most gracious are those who walk on the earth in humility and when the ignorant address them, they say, peace.

Similar to this verse, in Qesas (Surah 28:55) reads:

سلام عليكم لانتغى الجاهلين

Peace be to you, we seek not the ignorant.

Saying the above verse, the believers avoid continuing talks with the ignorant.

According to Hafezi (2012:138), in the other verses of the Qur'an (2:109; 4:63; 19:47-48; 43:88-89; 64:14), 'صفح' 'صنح' [to turn away and treat gently], 'اعر اض' [to disclaim], 'هجر' [to distance] and 'صبر' [to observe patience] are the features of peaceful discourse and talk.

2.Also known as Hazarat Abraham. 


\section{A vain talk from the Holy Qur'an's points of view}

By a vain talk, it means a word which is useless, so such an action is an obscene action which is necessary to be avoided (Tabarsi 1988:Vol. 7, 158; Raqeb \& Mohammad 1997:506). Also, Sajadi (2000:687) with a quotation from Tahanavi says the futile speech prevents humans from doing a true action and denies good actions from him or her. In the Qur'an, the futile speech has been attributed to the non-believers. There is no news of futile speech in the circles of the believers and the people of the paradise, a feature that has a close connection with lies and $\sin ^{3}$ so in any condition, the believers distance themselves from the futile words. ${ }^{4}$

\section{A false talk}

According to Raqeb and Mohammad (1997:243), by a false talk, it means a false word which is far from the truth. In some verses, such a talk has been mixed with tyranny and is attributed to the Quraish polytheists (Surah 25:4). The ignorance traditions such as ظهار [incestuous comparison] and belief in it is one of the other examples of false talk. The Qur'an rebukes such beliefs through this verse (Surah 58:2):

$$
\text { و انهم ليقولون منكر ا من القول و زورا ( المجادله 2) (2:) }
$$

'They use words both iniquitous and false', which in this case is giving the attribution of mother to the wife and it was invalidated by the Qur'an. The Qur'an considers a wicked talk besides idol worship as among the attributes of the polytheists which should be avoided by the believers. This commandment has been re-narrated in the Hajj (Surah 22:30).

فاجتنبو الرجس من الاوثان و اجتنبوا قول الزور ( الحج 30)

So shun the abomination of idols and shun the word that is false.

Tabarsi (1988:Vol. 7, 131) has considered telling lies and also the polytheists' words by which they consider a partner for Allah as the examples of false talks.

\section{Defamation talk}

Defamation talk means to attribute slander to someone or something, or to announce a truth as a false word or oppositely to attribute a false statement to a person which is not his or her word or belief. The Qur'an attributes such slanders to the polytheists and also believers of resurrection and divine verses and states:

انما يفترى الكذب الذين لا يو منون با يات الله واولئك هم الكاذبون ( النحل 105)

It is those who believe not in the signs of Allah, that forge falsehood, it is they who lie. (Surah 16:105)

The Qur'an has considered the following cases as examples of slander and announces those who forge falsehood as the cruelest individuals among all people:

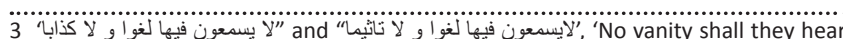
therein, nor untruth, No frivolity will they hear therein, nor any mischief' (Surahs 56: $25 ; 78: 35)$.

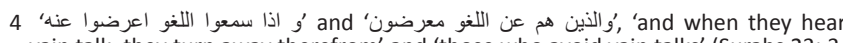
vain talk, they turn away therefrom' and 'those who avoid vain talks' (Surahs 23: 3 , 28: 55).
Attributing defamation words to the prophet in Qur'an (25:4), considering a partner for Allah (4:48), to announce some foods as lawful or unlawful without any religious bases (16:116), attributing a lie to Allah of the universe (6:93), and a lack of saying 'In the Name of Allah' while slaughtering animals (Surah 6:138). See also other Surahs (6:21, 93; 7:37; $11: 19 ; 18: 15 ; 29: 68)$.

\section{Characteristics of an ideal discourse in the Qur'an}

The holy Qur'an has considered various features for the ideal discourse which will have the best impact on the addressee, and their main points are presented as follows.

\section{Sadid [the solidified] words}

Sadid, a word in Arabic, means 'correct, proper, firm and solidified'. The Almighty Allah invites humans to speak with

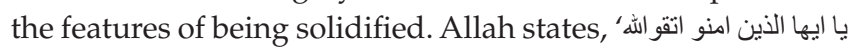
'و قولوا قو لا سديدا يصلح لكم اعمالكم (Surah 33:70-71) 'O, you who have believed, fear Allah and speak words of appropriate justice. He will [then] amend for you your deeds ....'. The opposite point to solidified and correct words is to speak in fragility which will lead to disruption in affairs (Surah 4:9).

\section{Lenient words}

Layen (lenient) words mean 'soft words' and talking with utmost compassion and favour. This type of speaking in the position of inviting towards the way of Allah enjoys the highest rate of impact on addressees. The necessity of lenient words is to have tolerance on the side of the speaker and considering a humane personality for the addressee by the other party. In the holy Qur'an (20:43-44), this personality has been attributed to many of the prophets. For example, while appointing Musa and Aaron, the Almighty Allah emphasises that while facing the Pharaoh, they should talk to him through lenient words, because there is a hope that he

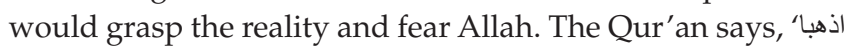
'الى فرعون انه طغى فقو لا له قو لا لينا لعله يتذكر او يخشى (Surah 20:43-44). 'Go, both of you, to Pharaoh. Indeed, he has transgressed. And speak to him with gentle speech that perhaps he may be reminded or fear [Allah $]^{\prime}$.

The secret of success of the holy prophet (p.b.u.h.) in his call was his gentle and good mood against the people. There is a reference to this feature in the verse 159 of Al-Imran. In another place, there is a reference to good and friendly talking with people which can be the main secret for the influence in the heart of people. It states, 'قولو اللناس حسنا' (Surah 3:83) 'Speak to people in good [words]'.

\section{The Noble words}

Karim in Arabic means 'profit', and if in Arabic one says ' 'كر امه فيه , it means that there is no generosity in him or her. In the perspective of the Qur'an, speaking should imply profitability; otherwise, it will be a waste. In the 
recommendations of the Qur'an to observe the rights of a father and mother, it has been stated that the children should talk to their fathers and mothers respectfully, humbly and in generous ways. It sates, 'وقل لهما قو لا كريما' (Surah 17:23) 'Speak to them in a noble word', that is to say, to talk to them profitably and respectfully. This style of speaking is of greater significance when the fathers and mothers are in the senile ages.

\section{The Meysur [easy] words}

Meysur means 'speaking in an easy way' and its application is where humans are unable to offer any financial or physical help to fellow humans, but he or she can open talks to remove their difficulties and request Allah to eradicate their problems. The message of the Qur'an in verse 28 of the Surat Bani Israel reads as describing that if you turn your face to help your relatives because of poverty, and if you are hopeful that you will be able to compensate their problems in the future with the help of Allah, then you should talk to them in a pleasant language to ease their problems. It states, ' ' اما تعرضن عنهم ابتغاء رحمه من ربك ترجو ها فقل لهم قو لا ميسور ا'But if thou turn away from them, seeking mercy from thy Lord, for which thou hopest, then speak unto them a reasonable word']. This is like the Meysur words and in another verse, the phrase of Maruf [known] words has been employed, which means talking based on the known customs of the society proportional with the status and conditions of talk (Surah 2:263).

\section{Baliq [eloquent] words}

Eloquent words means to talk in clear words far from ambiguity, such that it penetrates into the depth of the heart of the addressee. The view of the Qur'an about the solid speech is that it should be uttered transparently with no room for excuse. If this type of speaking is associated with admonishment, it will have a greater impact. So, addressing the holy prophet as the one who invites to truth, the Qur'an states:

$$
\text { فاعرض عنهم و عظهم و قل لهم فى انفسهم قو لا بليغا }
$$

So turn away from them but admonish them and speak to them a far-reaching word. Oh our messenger, stay away from their invalid claims but to admonish them and talk to them in a pleasant and effective words. (Surah 4:63)

\section{Haq [true] words}

An ideal talk is the talk which is in agreement with truth and far from any false, hallucination and invalidity. This type of speech is in the first rank the feature of words by the creator of the universe which is the whole truth. As it has been mentioned in al-An'am (Surah 6:73): قوله الحق 'His word is the truth'. Naturally, in pursuance of the Almighty Allah, the Allah and Truth Seekers should not talk except in truth. Such kinds of words enjoy specific purity which has و هذوا الى الطيب من :been mentioned in the verse (Surah 22:24) القول. 'And they had been guided [in worldly life] to good speech'.

\section{Feature of a corrective dialogue from the perspective of the Qur'an}

The dialogues of the prophets, wise people and righteous individuals with people, as the symbols of reformist dialogues, obey the following features precisely: ${ }^{5}$

\section{Rationalism}

According to Sharifi (2011:230), with quotations from a researcher named Al-Bash, the significance of rationalism in the dialogues of the Qur'an is to the extent that some consider the humans' reasons as real addressees of the Qur'an and believe that the Qur'an is constantly talking with the reason and intellect of the people.

Yes, the Qur'an encourages humans' intellect to cultivate and contemplate through questions and dialogue and then let him or her be free in selecting the way.

According to Razi and Hossein (1980), the first Sermon of Nahj al Balaghah, Ali (a.s.) also considers a rationalism as one of the prophet's objectives because in the prophets' dialogue with the people there is always an emphasis on rationalisation.

The prophets also associate their words with the rational measures to make the grounds easy for the addressees to accept them and also ask a reason from their own opponents against their baseless claims. For example, in one case, the claim of the Jews and Christians in entering into the paradise is challenged in the form of asking for a reason:

$$
\text { و قالولن يدخل الجنه الا من كان هودا و نصارى تلكى امانيهم قل هاتوا بر هانكم ان كنتم }
$$

And they say: none shall enter paradise unless he be a Jew or a Christian. Those are their vain desires, Say, produce your proof if ye are truthful. (Surah 2:111)

\section{Mildness in words and avoiding violence}

One of the factors of success of the prophets, in particular the prophet of Islam (p.b.u.h.), has been their good temper and mildness in words and practice. In the perspective of the Qur'an, the soft-natured attitude of the prophet of Allah (p.b.u.h.) in interaction with the people has been one of the main factors in attracting them towards Islam. The Qur'an states:

فبما رحمه من الله لنت لهم و لو كنت فظا غليظ القلب لا نفضو ا من حولك ( آل عمر ان 159) It is part of the mercy of Allah that you were lenient with them. And if you had been rude [in speech] and harsh in heart, they would have disbanded from about you. (Surah 3:159)

Also, Moses and Aaron, when dispatched towards the Pharaoh, are instructed to talk with the Pharaoh gently, perchance he could take the facts and fear of Allah (Surah 20:44):

But speak to him mildly; perchance he may take warning or fear of Allah.

5.For a detailed discussion of methods, models and outcomes of dialogue in the Qur'an, see the book Dialogue and Understanding in the Qur'an (Fazlulah 2001) 
Concerning the mild treatment of the prophets with their people, it would be sufficient to say that in their talk with their people they have used the phrase 'با قوم' [oh my people] and they have frequently requested divine grace and forgiveness for them, which is expressed in Hood Surah $(11: 28,29,30,50,61,64,78,84,88)$. Oppositely, when the people are making a rude treatment or attribute stupidity or misleading to the prophets, the divine prophets only used to

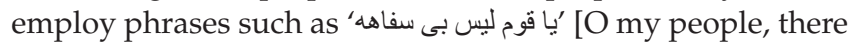

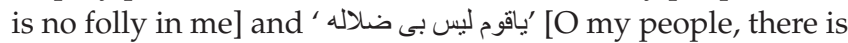
no error in me]; they were denying that wrong attribution and were not leading the case to quarrel and conflict (see also Surah 7:61, 67).

\section{Fact-centredness and truth-oriented attitude}

In the prophets' dialogues with their own people, a factcentredness and truth-oriented attitude has never been sacrificed for the sake of individual and social interests of the people, especially for arrogant and tyrannical people. According to the verses of the Qur'an (43:23, 24; 44:31), prophets in their prophetic mission have greatly emphasised monotheism, correction of the social corruptions including denouncing the overcharging, unhealthy sexual relations, and social tyranny. Because of their stable position in such a struggle, the arrogant and holders of welfare and wealth have always been in the front row of fighting against the prophets.

Oppositely, the deprived, unprotected and suppressed people were among the first followers of the prophetic missions whose number has been a few too:

But none had believed with him, except a few. (Surah 11:40)

What is important is that the weakness of the political and social power of the prophets and the shortage of faithful forces to them did not cause their exit from the factcentredness and truth-oriented attitude, and this did not make them resort to false and unfavourable actions to achieve their goals.

\section{Patience, endurance and continence in the path of dialogue}

Because of the fact that the opponents of the prophets were enjoying social power and also certain wealth and facilities, so their method was to mock the messengers and direct denial of the prophets (Sharifi 2011:232; and also Qur'an $13: 32 ; 21: 41 ; 46: 11 ; 64: 7)$.

Mocked were many messengers before thee but their scoffers were hemmed in by the thing they mocked. (Surah 21:41)

However, the Qur'an $(46: 35 ; 3: 184)$ has enumerated patience as one of the features of the divine prophets and recommends the Messenger of Allah (p.b.u.h.):

فاصبر كما صبر او العزم من الرسل ( الاحقاف 35) (did )

Therefore patiently preserve, as did all messengers of firm resolution. (Surah 46:35)
He is also given consoling words:

و ان كذبوك فقد كذب رسل من قبلى ( آل عمران 184)

Then if they deny you, [O Muhammad] - so were messengers denied before you. (Surah 3:184)

Thus, what is understood from the prophets' dialogue with people is their patience and endurance. Because of this, passion and good wishes are seen in the whole of their messages and words (Sharifi 2011:231). He (Sharifi 2011:232) also expresses, with reference to Hood Surah $(11: 28,88)$ using the patience, how prophets were trying to stand against the insults and false views while also insisting on old beliefs and ancestors' imitations to enable them to become closer to understanding the truth. However, these behaviours of the prophets were subject to bearing hard pressures, but it was fruitful in the long term and was followed by the absorption of Allah-seeking and fact-seeking humans and could fulfill the divine news which stated:

و العاقبه اللمتقين ( القصص 83)

And the end is best for the righteous. (Surah 28:83)

\section{Question and questioning in the process of dialogue}

In the path of a creative and fruitful dialogue, questions have a special position. In many verses, raising certain questions, the Qur'an (3:44, 6:50; 29:43) makes people think and meditate deeply. In the prophets' dialogue with people, the interrogative model has been frequently employed. In this model, raising certain questions, the divine prophets such as Abraham and Moses (a.s.) have made the people's mind to be curious and they have also been responsive to their questions. For example, Abraham (a.s.) in the position of dialogue asks his uncle, the idol cutter:

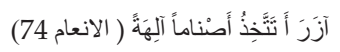

Do you take idols as deities? Surah) 6:74)

And after breaking the idols and hanging the ax on the hands of the big idol addresses his people and says: The big idol has broken the rest of the idols. If they speak, then ask them. (Surah 21:63)

It was this very call to question by Abraham who made his people think and they said to Abraham:

Then were they confounded with shame: They said: Thou knowest full well that these idols do not speak! (Surah 21:65)

Abraham also utilised this opportunity and said:

قال افتعبدون من دون الله ما لا ينفعم شيئا و لا يضركم (الانبياء 66)

He said, Then do you worship instead of Allah that which does not benefit you at all or harm you?) Surah 21:66)

And this by itself was another question which he asked his people.

According to the verses of the Ash-Shu'araa Surah (26:16-29; 3-35), in inviting the Pharaoh to monotheism and request for 
the freedom of the Israelites, Moses replies to a series of his questions about Allah. It is strange that in a condition in which Moses responds to the Pharaoh's questions patiently, it is the Pharaoh who loses his temper and patience and adopts the route of threat and violation and says: 'If thou takes any Allah other than me, I will certainly put thee in prison' (Surah 26:29). It is in this time that Moses inhibited the Pharaoh by presenting his own miracles.

Anyway, raising the questions and responding to the people's questions have been effective in prophetic missions and presenting constructive and fruitful dialogues, which has been utilised by the prophet of Islam (p.b.u.h.) as well.

\section{Conclusion}

1. The culture of dialogue in the Qur'an enjoys a high position and is very frequently used. There are various types of dialogues in the Qur'an such as dialogue between Allah and the symbols of the universe, dialogue between humans, and so on.

2. The logical model of dialogue in the Qur'an has been presented under the three models of wisdom of reasoning, admonishing and challenging (discussion).

3. Ideal speech in the Qur'an has been described in the Qur'an with features such as solidified, lenient, truth, pleasant, clear, known, noble and truthful and, oppositely, features such as force, invalid, accusation, false and waste are signs of unfavourable speech.
4. Intellect-oriented attitude, avoiding violence, seeking truth-oriented attitude, patience and self-contained attitude and, finally, being a questioner in the process of dialogue are among the indicators of corrective dialogues in the perspective of the Qur'an.

\section{Acknowledgements Competing interests}

The author declares that he or she has no financial or personal relationships which may have inappropriately influenced him or her in writing this article.

\section{References}

Fazlulah, M.H., 2001, Dialogue and understanding in the Qur'an, Hermes Publications, Tehran, Iran.

Hafezi, M.S., 2012, Model of communications in the Quran, Avay-e Danesh Gostar, Tehran, Iran.

Khansari, M., 1980, Formal logic, Agah Publication, Tehran, Iran.

Muslim open source community, Noble Quran (in English), viewed 01 July 2018, from www.quran.com

Qur'an, 2012, Osve Publisher, Iran.

Raqeb, I. \& Mohammad, H., 1997, Almofradat, Dar al Kitab al Elmiya, Beirut.

Sajadi, S.J., 2000, Dictionary of mystical terminologies, Tahouri Publications, Tehran, Iran.

Razi, S. \& Hossein, H., 1980, Nahjalbalaqa, Nahjolbalaqa Foundation Publications, Tehran, Iran.

Sharifi, M., 2011, Rules of oration and dialogue in the Qur'an, Khurshid-e Baharan, Tehran, Iran.

Tabarsi, F.-H., 1988, Majma al Bayan, Dar al Marefah, Beirut.

Tabatabaei, S.M.H., 1990, Tafsir e Almizan, Beirut, Moassesat al Elmi, Tehran, Iran. 